\title{
Hormone Receptor Positive Breast
} Carcinoma

National Cancer Institute

\section{Source}

National Cancer Institute. Hormone Receptor Positive Breast Carcinoma. NCI

Thesaurus. Code C157056.

A breast carcinoma that is positive for estrogen or progesterone receptors. 